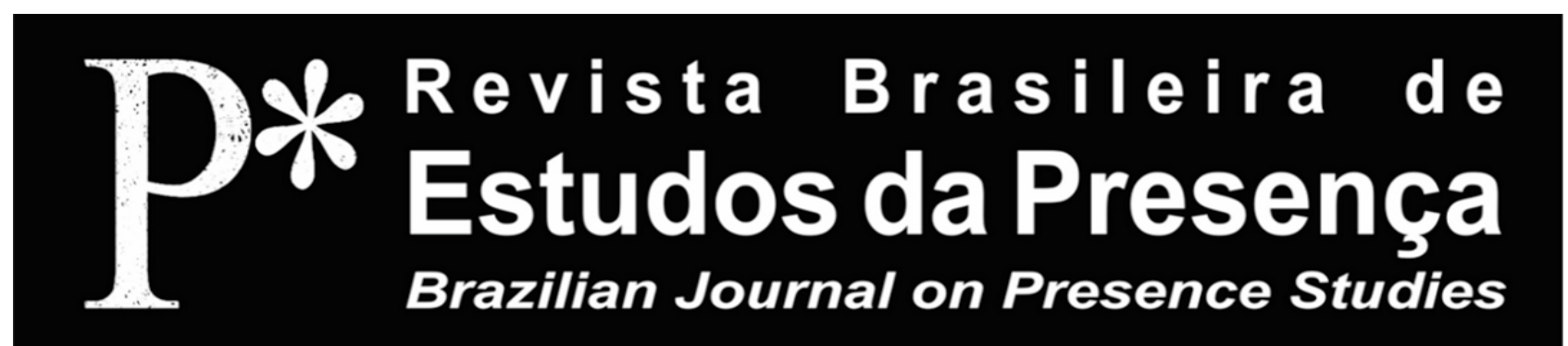

CONTEMPORARY TOPICS

E-ISSN 2237-2660

\title{
The Monstrous Flesh: collective bodies and the State- Form in Modern Mesopotamia
}

\author{
Iman Ganji' \\ 'Freie Universität Berlin - Berlin, Germany
}

ABSTRACT - The Monstrous Flesh: collective bodies and the State-Form in Modern Mesopotamia The Middle East is in chaos. Having been described as monstrous, the Islamic State (ISIL) has been defeated only to come back as a chronic guerrilla style insurgency and the shadow of further conflicts that are still looming in the region. The following artide takes up this situation through the concept of the biopolitical monster as the common body of resistance and strugge, exploring the liberatory aspects of this concept in terms of organization and political autonomy, and argues that ISIL has more in common with the State-form than with the monstrous. Discussing the colonial and neo-colonial aspects of the situation, the case of Kurdish Northern Syria will be presented in contrast to the ISIL. It continues to argue for a social monstrous flesh as the performative body of contemporary protest movements, tracing back the rhizomatic etymologies of monster to Aristotle and early Islamic philosophers, drawing inspirations mainly from the tradition of immanent thought and its contemporary thinkers such as Foucault, Deleuze, Guattari, and Negri.

Keywords: Biopolitics. Monster. Political Autonomy. Islamic State. Colonialism.

RÉSUMÉ-La Chair Monstrueuse: les corps collectifs et la forme étatique en Mésopotamie moderne-Le Moyen-Orient est secoué par le chaos. Ayant été appelé monstrueuxx, l'État Islamique (EI) a été vaincu uniquement pour ressurgir sous forme dinsurrection permanente à caractère de guérilla et comme ombre des conflits qui continuent à sannoncer dans la région. Le présent article aborde cette situation à travers le concept du monstre biopolitique en tant que corps commun de résistance et de lutte, en explorant les aspects libérateurs de ce concept en termes dorganisation et d'autonomie politique, et considère que l'EI relève davantage de la forme étatique que de la monstruosité. En examinant les aspects coloniaux et néocoloniaux de la situation, le cas de la Syrie du Nord kurde sera présenté en opposition à l'EI. Puis, lartide plaidera pour une chair sociale monstrueuse constituant le corps performatif des mouvements de contestation contemporains, en traçant lorigine des étymologies rhizomatiques du monstre chez Aristote et les premiers philosophes musulmans, tout en sinspirant d'une tradition de la pensée de limmanence et de ses philosophes contemporains, tels que Foucault, Deleuze, Guattari et Negri.

Mots-clés: Biopolitique. Monstre. Autonomie Politique. L'État Islamique. Colonialisme.

RESUMO - A Carne Monstruosa: corpos coletivos e o Estado-Forma na Mesopotâmia Moderna - O Oriente Médio está em caos. Descrito como monstruoso, o Estado Islâmico (EI) foi derrotado, mas retornou como insurgência crônica no estilo de guerrilha e como sombra de outros conflitos que assomam a regiáo. $\mathrm{O}$ artigo retoma esta situaçáo por meio do conceito de monstro biopolítico como o corpo comum de resistência e luta, explorando seus aspectos libertadores em termos de organizaçáo e autonomia políica, e sustenta que o EI tem mais em comum com o Estado-forma do que com o monstro. O caso do Curdistão Sírio será apresentado em comparação com o EI. Defende uma carne social monstruosa como corpo performativo de movimentos contemporâneos de protesto, investigando as etimologias rizomáticas de monstro para Aristóteles e antigos filósofos isâmmicos, inspirando-se principalmente na tradição do pensamento imanente e seus pensadores contemporâneos, como Foucault, Deleuze, Guattari e Negri.

Palavras-chave: Biopolítica. Monster. Autonomia Política. Estado Islâmico. Colonialismo. 


\section{Introduction}

An ancient-like barbarity; a monster of non-civilization: this is how the image of the Islamic State in Iraq and the Levant (ISIL) has been formed through media reports. Even Joe Biden, the former vice-president of the United States, promised his fellow Americans that they will follow ISIL "terrorists" to "the gates of hell", because "hell is where they will reside" (Lowery, 2014, n. p.).

It is said that monsters come from hell, but one may still wonder about the nature of the monster and of the subject naming it. The monster could be a Leviathan, the one that announced, "everything under heaven belongs to me" (Job 41: 11), that declared the natural commons (i.e. earth, air, water, everything under heaven) as its property, and that was summoned to fill the mythical foundations of the modern Nation-State and its era of public/private dichotomy. Alternatively, the monstrous could be those witches who were often revealed, not surprisingly, during the peasant revolts against the nascent bourgeois State - opposing its appropriation of common lands - and were hunted down, burned and destroyed in the aftermath (Linebaugh; Rediker, 2000). Or is it another Caliban, subjugated to its civilized colonial Master, rejecting him only in order to learn the hard way that colonialism is for its own good?

The skeptic may also ask about the monstrous body and "what it can do": is it an organism with one or several heads, homogenous but divided, an oedipal "Frankenstein" which is only capable of resentiment against the Father, or an "Acéphalic" labyrinth, which posits community against fascism, "against mass [...] against the imposture of the individual", a community "distinct from the community of blood, earth, and interests" (apud Kendall, 2007, p. 138)?

Given the situation in the Middle East and ISIL's unforgivable crimes, it is self-evident now that ISIL is a reactionary force. But reactionary in what sense? Is it reactionary like its image in (the majority of western) mainstream media, which portrays them as an ancient and pre-modern monster, a form of sociality most distant and thus most opposed to Western or modern values? 
The following article will concentrate on the problem of the monster, and through the tension inside this word, it will deal with the bodies that are now trapped in the Middle East by a global regime of visas, regulating the freedom of movement. It aims to show that the determinate content that constitutes the hard core of ISIL, is only filled by mystifications through the emergent post-modernized public beheadings and all other selfdocumented and self-mediatized atrocities. Contrary to the terrifying and senseless absurdity of ISIL, this text seeks to foreground the voices of those Middle-Eastern bodies that do matter: the bodies of biopolitical monsters. Trying to situate the contemporary case of ISIL and Kobani in the history of monstrous thought and to clarify the arguments and concepts used in the first section, the article will end with a section devoted to the etymological and philosophical inquiries on the monstrous flesh.

\section{Natural Bodies versus Monstrous Bodies}

To understand the modern natural form for collective bodies and its threatening monstrousness, one should examine the normative and normalizing aspects of modernity in relation to collective bodies. Modernization, the process of (re)producing concrete (trans)formations under the name of modernity in different parts of the world, is exemplary in this regard. This concept "established itself in the political-ideological climate of the years after the second world war" (Martinelli, 2005, p. 1), of the period of decolonization and post-colonial nationalism on one hand, and of the Cold War on the other hand. Moreover, these political and cultural modernizations are proper to the modern economic paradigm, reappropriated according to each local context. Consequently, the way in which collective bodies are allowed to be formed via modernity's construction and organization of flesh, is now something that is simply presupposed.

The outcome of this process of modernization is the nation-state, which is viewed as the natural and exclusively legitimate form of the political organization of collective bodies; a process whereby the one divides itself into two and results in a ruling bodiless head as the State and a ruled headless body with a hierarchy of organic divisions and organs. Although no longer the center of power in the age of control societies, the nationstate still remains valid as the natural form of organization and one of the 
most important institutions of the globalized network of (post)modern power relations.

Particularly after 9/11, the imposed global framework for progress, the economic and political principles called the Washington Consensus ${ }^{1}$, presents itself in the form of a binary that refers to an identity-based Statepolitics: Bush or Bin Laden. This political dead-end of globalized capitalism offers the nation-state as the only political form proper to our contemporary world, where what is decided upon is merely this political form's material content: theocratic authoritarian or neo-liberal and representative.

And it is because of the State-form's possible authoritarian, hierarchical, centralized, and exclusive content, that the State itself has been subjected to countless critiques in the history of critical philosophy. However, and without bringing these already clear shortcomings onto the table again, the salient fact to keep in mind is that the monstrous of the modern era always appears as a refusal of the natural-legal composition of collective bodies, and goes beyond pure negation in order to experiment with the alternative.

\section{The Case of the Islamic State}

The latest kind of a post-colonial State-making process is the so-called "Islamic State" (originally known as the Jihadi group "Islamic State in Iraq and the Levant"). It is indeed the most recent (self-)declared State in the world. The declaration of the Caliphate, the performative action of saying "I am the Caliph" by Abu Bakr al-Baghdadi and of expressing allegiance (Bey'at, بيعت) by the subjects in Mosul's Grand Mosque, 5 July 2014, was the last stage of symbolically establishing a State. The rest has been a period of war, of absence of politics. Why an absence of politics? For the simple reason that politics as defined by State-making processes is always a people's politics; that is, it always presupposes the collective act of self-organizing difference and dissensus in an egalitarian, non-hierarchical way.

Of additional importance here is the etymological meaning of the Arabic word for State, Dowla (دولة), which means glory etymologically. And glory, according to Giorgio Agamben's discussion on the secularized Christian theological grounds of the modern Western sovereignty- 
governmentality, is the empty locus of mediation between the transcendent sovereign power and the immanent governmentality's techniques, the divine and the material (2011). In other words, ISIL isn't simply the manifestation or proof that Christian and Islamic notions of glory are identical. Rather, ISIL is borrowing a fundamentally modern/Christian political discourse in order to justify itself within the contemporary world. And for this reason, Islamic does not modify the substance of its political form and merely is a way of designating its difference from other nation-states. Thus, Islam merely serves as an adjective as a qualification to the political form of content corresponding to the classically universal form of expression that has been for a long time called the State.

The self-declared Islamic State came into existence in a region marked by a colonial agreement, with a Caliban sleeping on its soil ${ }^{2}$. The still official map of the Middle East was indeed shaped with the Sykes-Picot Agreement in 1916. But the war in Syria and Iraq and the declaration of the most recent State of the world, the so-called Islamic State, has actually changed the post-World War I setting in the Middle East (Bowen, 2013).

Moreover, and despite the fact that all national borders are in some sense artificial (i.e. historically constructed), the particular artificiality of Syrian-Iraqi border established by the Sykes-Picot Agreement is horrifyingly absurd. The Agreement, which was initially intended to be between the colonial powers of the Allies in World War I, Britain, France, and Russia, was ultimately made final in secret between France and Britain alone (O'Sullivan, 2003). Sir Mark Sykes, a senior British diplomat, and Francois Georges Picot, the former French council in Beirut, signed the agreement on May 16, 1916, according to which two colonial powers were allocated the Arab provinces of the Ottoman Empire (today's Iraq, Syria, Jordan, Lebanon, Palestine, etc.). The absurdity is best revealed by Sykes Statement in Downing Street at the end of 1915: "I would like to draw a line from the 'e' of 'Acre' to the last 'k' in Kirkuk' (Barr, 2012, p. 12). One could even say that what is at work here is a certain application of Shakespeare's Tempest, where Caliban could be regarded as an image of the monstrous in the region, a monster that must be tamed, trained, or organized properly.

In the original drama, when Prospero, the cultured Duke familiar with philosophy and astronomy, landed on Caliban's island, he had no choice but to imprison this monster with unknown powers of magic. In any case, 
the monster was not fully docile and obedient. He was deceived by the ignoble Stephano, and accepted him as a god. The two masters were competing over the source of production, the monstrous flesh as the common. But in the concluding act, Caliban finally realized that not only was Stephano not a god, but also that the transcendent position of the colonial Master was only proper to the eugenic Western politician, Prospero.

The Caliban of the modern Mesopotamia is also already subjected to a turned-into-master slave authority, to the ISIL-Stephano's rule trying to undermine the eugenic masters of the post-colonial powers. It has thus entered a dialectical relation of master-slave, only in order to finally find the true civilized former master better than the other one. In other words, ISIL is not a radical political group, but has been feeding - like a parasite - on collective bodies of resistance and struggle in that region. For Caliban "[...] is monstrous only to the extent that his desire for freedom exceeds the bounds of the colonial relationship of biopower, blowing apart the chains of the dialectic" (Hardt; Negri, 2009, p. 98).

Additionally, just like any other State that couples with its nation, the so-called Islamic State also tries to make Umma (امة) - a traditional name referring to the world-wide community of Muslims - its nation. By definition, the nation is a collective body characterized by a homogenous identity. When modernity comes into an actual territory, it triggers a process of homogenizing the collective body, excluding some groups from the national identity. To continue with the example, one should note that in its pre-modern history, Umma was never a nation. Instead, Umma was a heterogeneous whole subordinated to the transcendent point of Caliph (sovereign's) authority. To become a nation, it could not remain the same. It must be secularized as the divine glory has been secularized in Dowla. In this case, a particular Islamic identity has been coined for national identity and ISIL is promoting a very particular kind of Sunni Islam that excludes all other branches, including various branches of Shiism, mystical Islam, and so forth, as well as other believers and non-believers.

Additionally, the term State itself comes from the pre-Indo-European root sta-, similar to Persian -stan (ستان-, country), referring to what stands or what is (just like the ancient Greek word státis also designates something as a standing still). On the other hand, stásis also refers to a long history of civil wars. The Greek were fighting to show who the real aristocrats are, those 
eugenic people proper to rule. Coming from arete (excellence) and aristos (the best), aristocrats means the best people, which according to Platonic thought are allowed to impose their authority. If stásis, the term for civil war, shares the same root with the State, both coming from the founding meaning of being permanent and stable, what is ontogenetically permanent then?

Rather than a permanent entity, this stasis proper to States refers to an interruption of movement or kinesîs, understood as the only thing that is permanent. However, and to avoid confusion, this alleged permanence of kinesîs must be understood through its etymological derivation from tasis, which signifies tension, intensity, force, antagonism, as well as the prolongation of a sound or utterance for no other reason than the pleasure of its being said or heard. In this etymological drama, one could say that what has a permanent role, the one that endures permanently, is not the State (the standstill of constituted power), but paradoxically the movement and its tension (the constituent power), the pleasurable self-utterance of a people that sometimes halts with the loud State's "clariounes, that in bataille blowen blody sounes" (borrowing from Chaucer's The Knight's Tale): and the bataille is the State's civil war against the people. And regarding the relation between the State and the movements and tensions it interrupts, the Foucauldian principle of "where there is power, there is resistance..." (Foucault, 1978, p. 95) is helpful in clarifying what is at issue: before the suppression and oppression succeeds, resistance and rebellion (i.e. the constituent power of the non-eugenic, and the poor) exists as ontologically prior to the State's constituted powers.

Thus, what is permanent is not the State, but the civil war, the flux of the constituent power of the non-best. Consequently, we are compelled to say that the State is mere reaction; that which follows from and is subsequent to the ontological priority of stásis. And as far as the constituted power of the State exerts itself, there is always a resistance against the homogenous identity imposed on the flesh, trying to go beyond the natural body and its corresponding power relation. "There is no social system that does not leak from all directions, even if it makes its segments increasingly rigid in order to seal the lines of flight" (Deleuze; Guattari, 2005, p. 204). Even in Raqqa, the capital of this most recent and brutal State, graffiti painters risked their life to write slogans against ISIL on the walls. Not 
unlike the "Standing Man" of Taqsim Square, Suad Nofel made her "onewoman rally" protest every single day for three months in front of ISIL headquarters in Raqqa, holding a sign with these words: "No for oppression, no for unjust rulers, no for atonement, and yes for thinking!" (Taleb, 2014, n. p.).

These leakages, or lines of flights, can nevertheless lead to two different politics: anti-modern identity politics, or alter-modern non-identity politics, from which the former stands for the enslaved Caliban and its slave-master, and the latter refers to the monstrous flesh. Nonetheless, it must be noted that the Caliban was already there before the agreement, since it was the only source of constituency, the only force capable of producing wealth on the island. Having resisted and failed in the face of the Sykes-Picot Agreement, it had to also deal with the 2003 invasion of Iraq and the transnational war, which subsequently unfolded on Syrian territory. And if it is the "revolution [that] is monstrous" (Hardt; Negri, 2009, p. 332 ), then one must take Benjamin's warning seriously that fascism comes after revolutionary failure (apud Grigg; Sharpe, 2011). And it is regarding this question of "what does revolutionary failure look like?" that we can return to the history of State formation and the civil wars it interrupts in a new light.

The Sykes-Picot Agreement was itself a reaction of terrified colonial powers facing the rise of grass-roots movements in the region, which saw the British Empire funding some factions in Arab uprisings against Ottoman rule, promoting Arab Nationalist Movements. It famously promised some Arab nationalist and royalist figures that it would allow them to have independent Arabic Kingdoms. And although these figures were loyal to the commanding colonial authority, the promises were never realized (Tanenbaum, 1999). Instead, the colonial interventions of Britain, France, and later Nazi Germany, led to an organic, homogenous, and closed hierarchical body of Caliban's monstrous flesh. In other words, the Arab movements transformed into an identity-based process of nation-state making - e.g. the Ba'ath (البعث, "renaissance") movement that was supposed to bring about the new revealed itself as the "eternal recurrence of damnation" (Adorno, 2005, p. 236). The Arab Socialist Ba'ath Party gave birth to two single-party Nation-States in Syria and Iraq, both of them 
marked with genocide and ethnic cleansing while the opposition of the Young Turks led to the nationalist republic of Mustafa Kemal Atatürk.

At the same time, another movement emerged insisting that they had true Islamic roots: the Muslim Brotherhood. The Muslim Brotherhood is however but one branch of the movement under question, which is now mainly oriented toward a parliamentary stance. With the slogan, "God is our objective. The Prophet is our leader. The Qur'an is our law. Jihad is our way. Dying in the way of God is our highest hope. God is great!" (Ali, 2011). The Muslim Brotherhood reveals the extent that the foundations of modern political form of the State are compatible with the legacy of the socalled tradition. After all, how could it be possible to address and name the tradition without situating oneself within the singularly modern discourse of the nation-state? Now, on the one hand, we see such processes playing out with respect to the protest movements of Iraqi Sunnis in the 2000s, which followed the establishment of a Shia majoritarian government and were eventually opportunistically replaced by Al-Qaeda's militarization. And as the second generation of Al-Qaeda that emerged in Iraq made clear, the aim of their Jihad was the establishment of a State.

In his treatise "The Management of Savagery" (2006), Abu-bakr Naji, a Jihadi author who is said to be influential on the ISIL leadership, identified the necessary and gradual steps required for the construction of an Islamic state. According to Naji, this notion of the management of savagery refers to a period in which the power of central State will collapse due to Jihadi attacks and "the power of vexation and exhaustion." Consequently, an area of limited Statehood, which he calls a territory of savagery, will emerge. As Naji explains, it is this period of time that favors the attempt of forming a State by developing welfare and public services, and by establishing military, educational, and intelligence institutions. The information that has come out of the ISIL territories through video documentaries and reports shows a theoretical and practical compatibility between the stages explained in Naji's treatise and ISIL's actual strategy.

On the other hand, the Syrian revolution has been trapped in a war between different nation-states that have been channeling the Syrian resistance's potentiality into identity-politics, by raising their own versions of enslaved Calibans out of the monstrous flesh. ISIL feeds on the same 
monstrous flesh, and more successfully than other Jihadi groups, since it manages to give a monstrous image of itself.

However, despite their differences and once the non-representable disaster in Iraq and Syria started to be represented through the mainstream human rights discourses, the dominant lens of mainstream analysis became the figure of the victim. This figure of the victim, however, is the paradoxical subject of human rights: unable to claim its own rights and, thus, in need of the Other (the master) to reclaim it on behalf of him either by issuing Statements and declarations, or by missiles, drones, and bombs. Sometimes, however, this victim presents reactions of its own. Pointing to the oppression he underwent, the victim screams that he does not want the kind-hearted mastery of the Global North, thus transgressing the master's rules and laws to exhibit his agency. In other words, although the victim could commit reactionary and suppressive acts of violence, he is still trapped in the economy of human rights discourses. It is here that the image of the victim connects itself to the gruesome images of beheadings and mass murders, in order to propagate the illusion of a monstrous struggle: a strategy directed at the victims of the unequal divisions between the North and the South, of the artificial (post-)colonial national borders. The paternal Other also makes another victim out of the emergent monstrous images, trying to punish the former one: it is the unfortunate convergence point between ISIL's media strategy and that of the global mainstream media.

To summarize, the so-called Islamic State was not a monster; on the contrary, it was based on the very modern eugenic principles: domestication of femininity; exclusion of all minorities (religious, sexual, gendered, and so on); setting up juridical, penal, religious, educational, military, and security institutions; attempting to regulate and govern the very minute daily activities of its subject; its hierarchical organization of the collective body around the transcendent point of Caliph. However, even with beheadings, genocides, bloodsheds, and self-exploding bodies, ISIL was unable to acquire the constituent power of the monstrous. Longing for a homogeneous body, ISIL is gregarious in Nietzschean terms; while the monstrosity is "the fact of the particular case" (Klossowski, 1997, p. 9). 


\section{Kobani's Caliban}

In the beginning, there was the monster; and the monster was free. The Caliban had been freely wandering on its island before the colonial aristocrat, the well-born, departed into the exterior (sea) in search of a land. The monster lurking on the fold of this exterior (on the island) had to be stopped, chained, and trained; for it is the sole source of creation, of the produced commonwealth. The "monster is common", writes Negri (2008, p. 205). But the monster is also the struggle inside what is common, as it incarnates the autonomous, anti-essentialist multitude (flesh is the monstrous body). Thus, the plot of this monstrous unfolding could very well be different from its Shakespearean dramatization.

The Sykes-Picot Agreement, along with the national borders it would impose and go on to defend had particularly dire consequences with respect to the Kurdish people, who enjoyed a relative autonomy before the fall of Ottoman Empire. After the borders were drawn, Kurds largely found themselves on the "borderlines" of four nation-states (Iran, Iraq, Syria, and Iraq) in both senses of the term: being marginalized by hegemonic national identities, and at the same time, literally situated in the official bordering regions. Hence, the very existence of the Kurds had been a challenge to Sykes-Picot colonial borders.

After the proclamation of the Republic of Turkey, the nation building process of this single-party State - as an inevitable part of its "modernization" - started with a focus on "an ethno-nationalist ideology despite the multiethnic and multilingual composition of the country" (Dayan, 2014, p. 1). The eugenic mystifications of the constituted power assumed the figure of a "happy Turk;" a figure that also dictated that a fully Turkified collective body had to be formed. Ismet Inonu, the second president of the Republic, explains this belief with a kind of violence proper to it:

We are frankly nationalist, and nationalism is our only factor of cohesion. In the face of a Turkish majority, other elements have no kind of influence. Our duty is to turkify non-Turks in the Turkish homeland no matter what happens. We will destroy those elements that oppose Turks or Turkism (Inonu apud Dayan, 2014, p. 1). 
As a deviation from the natural "Turkish" collective body based on blood and soil, the Kurds became that which was monstrous in the eyes of the Turkish nation-state; a people whose very unintelligibility led to its discursive exile on the exterior of Turkish identity to such an extent that Kurds were even referred to simply as "mountain Turks".

This (Kurdish-)Caliban, however, seems to have been raised once more in our contemporary moment. For when nobody could stop the fascist ISIL's apparatus of capture, it was this Kurdish monster, manifesting its joyful strength in Kobani, which was capable of stopping the Jihadists' military with its war machines. Moreover, in a passage in the Theses on the Concept of History, Benjamin writes that today's critical "mode of thought" needs to make the world "repugnant", or one might say, monstrous. For the politicians "in whom the opponents of Fascism had placed their hopes" compromised with fascism, and for this very reason, the monstrous mode of thought must intend to free "the political child of the world from the nets in which they have ensnared it" (Benjamin, 2003, p. 393). And this is certainly the case with Kobani's monster, to which "Kurdish" serves only as a common name, and not a signifier of any identity.

But what has created the monstrous flesh of the struggle in Kobani occurred before this "canton", thanks to its daring defense, transformed into a spectacular image in the mainstream media. The singular and monstrous form-of-life which is tied to the name of Kobani, its becoming "canton" instead of a city-State, the organizing form of the collective body, and the minor narratives about the life of its militants construct together the "truth" of Kobani, where comrades dance and sing for the living as well as for the dead, where the seemingly traditional marginalization and domestication of women have no place, and where identity is refused.

Kobani is one of the three Rojava Cantons in Syria. Insisting on the right to self-determination, these cantons have formed an autonomous territory. "Canton" originally meant "region or corner" and referred to autonomous members of the Old Swiss Confederacy during the $14^{\text {th }}$ and $15^{\text {th }}$ century with their own form of direct democracy. Inspired by the Idea of cantons' confederacy, residents of Rojava have written their own, still limited, constitution for an alternative organization of the collective bodies that starts with the following: 
We, the people of the Democratic Autonomous Regions of Afrin, Jazira and Kobane, a confederation of Kurds, Arabs, Syrics, Arameans, Turkmen, Armenians and Chechens, freely and solemnly declare and establish this Charter. In pursuit of freedom, justice, dignity and democracy and led by principles of equality and environmental sustainability, the Charter proclaims a new social contract [...] we, the people of the Autonomous Regions, unite in the spirit of reconciliation, pluralism and democratic participation $[\ldots]$ in building a society free from authoritarianism, militarism, centralism and the intervention of religious authority.

However, the manner in which militants from other regions have been joining the struggle in Kobani, and the historical formation of the collective body in this city, points more toward a monstrous alliance with the collective body, rather than a social contract, as a way of making "being-together".

Kobani is a city made by World War I and its consequent nationalist States. Its name means "company" and refers to the German Railway Company in charge of building the controversial Berlin-Baghdad railroad. During the Armenian genocide in the Turkish Empire, refugees built Kobani near the railway, and were joined later by the Kurds who fled the Turkification of the Turkish Republic. The liminal city was again divided by a new national border in the aftermath of Sykes-Picot and found itself situated literally on the borderline between Turkey and Syria (Taştekin, 2014). Now, this hybrid one-hundred-year-old monster presents itself with a new collective body; heterogeneous, multiethnic, and multilingual; which actively refuses the "natural" modern form of the nation-State. It is for this reason that any discourse regarding the nature of Kobani's "being-together" cannot be understood simply through the modern and liberal notion of the social contract.

Today, terror and bombing, shooting and slaughtering, knives on necks and explosive belts on torsos, bombs hidden inside bodies, all indicate that indeed a spectre is haunting our contemporary world - the spectre of death. Dying peacefully in a white isolated room, "the loneliness of dying" as Elias (2001) puts it as an existential catastrophe, is now a miracle in Mesopotamia. It is exactly in the face of such situation that the autonomous Caliban of Kobani stands alone an image of the very meaning of politics today insofar as politics is defined as the self-determination of collective action by a people enriched with differences, who "unfold the consequences of a new possibility" (Badiou, 2008, p. 31). And it is in situations such as 
these that we are in need of "new giants and new monsters to put together nature and history, labor and politics, art and invention in order to demonstrate the new power that is being born in the multitude" (Hardt; Negri, 2004, p. 194). With its political and creative art of making war machines, even in the literal sense of the word, the Caliban of Kobani demonstrates the power of the flesh, resisting the advance of the gregarious slave-master resentiment for the sake of the particular case.

\section{Rhizomatic Etymologies}

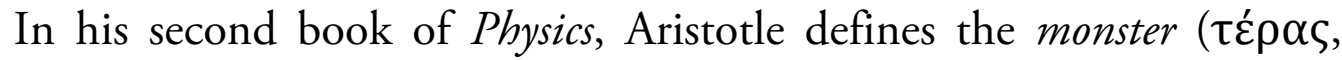
teras) as a mistake in or a deviance from Nature, such as the malformed new-born babies or hybrid animals with human bodies and animal heads. Jacques Derrida refers to this early medical definition of the monstrous, when he writes that "nature denaturing itself, being separated from itself, naturally gathering its outside into its inside, is catastrophe, a natural event that overthrows nature, or monstrosity, a natural deviation within nature" (Derrida, 1997, p. 41.Emphasis added).

The word " $\tau \dot{\varepsilon} \rho \alpha \varsigma$ refers firstly to a wondrous and therefore terrifying omen of a future event, sent by gods and needing interpretation" (Mollendorf, 2009, p. 94). Teras means sign, but mostly, a sign of threat that contains a divine power in itself. Etymologically, teras comes from the proto-Indo-European ${ }^{*} k^{w} e r$ - (to do, to build, and to make) which keeps its form in the Indo-Iranian word $k \bar{a} r$ (كار, meaning work). The Latin counterpart to teras, monstrum, shares the important meanings of the Greek term, as it comes from the same root with the verb to demonstrate and the noun demonstration. However, the signifying meaning of the monster has a particular nature: it signifies itself, the warning of a threat to the so-called humanity, by its pure presence. It does not need to even do something: its mere apparition, like the divine, is its action, turning a situation into an inhuman one; simply because monstrosity first of all refers itself to the pure potentiality of building and making $\left({ }^{*} k^{w} e r-\right)$.

Additionally, the monster as a category of the living is always situated between the human and the animal - hence why numerous monsters are animal-human hybrids or some animals have been called monsters, when threatening the humans. This in-between-ness of the monstrous made it 
difficult for human being to be able to identify it, to place it in the epistemological functions of similarity and comparison in natural sciences, and to categorize it for proper logical understanding. Perhaps, it is the reason why teras and monstrum comes originally from such abstract meanings, and only after that they could refer to natural manifestations of the denaturing monstrosity.

Ifrit (عفريت), the name for supernatural monsters in Arabic, reveals the same abstraction-technic in the face of monsters. The word comes from Iferr ("), strong and huge or malicious evil, and simultaneously from afar (عَفر), "soil, dust, or to disperse like dust". On the other hand, it comes etymologically from the Middle Persian āfrìt (آفريدن) which means creation. Thus, ifrit is not only very strong, but also as volatile and fleeting as dust, while these characteristics belong to its creative power. According to Islamic mythologies, it is also said that ifrit is made out of fire (or smoke), (and as its rare appearances in the Qur'an testify, ifrit also evades the possibility of it ever being fully known. In Surat An-Naml (27:39-40), an ifrit promises "King Solomon" to bring him "the Queen of Sheba's throne" in an instance: "I will bring it to you before you rise from your place, and indeed, I am for this [task] strong and trustworthy." The last clause, which begins with "indeed", a rough translation for انّى (ennī) that functions as an emphasis, reveals that nobody, even a messenger of God such as Solomon who, according to Qur'an, knows everything in the world, even the language of non-human creatures - could know an ifrit completely, or could predict its actions. That is to say, even divine knowledge does not know what a monstrous body can do for monsters challenge the transcendent.

\section{Political Monster: a case of fascination}

Lurking smoothly into the Modern era, monsters are far from being extinct: they "have always defined the limits of community in Western imaginations" (Haraway, 1991, p. 181). That is why the non-natural and non-identifiable transgressive monster has been long a source of fascination for modern and contemporary thinkers.

Looking from the perspective of the monstrous, however, modern is itself a problematic notion. The word modern comes from the Late Latin 
word modernus, which is itself derived from the Latin root modo (just now, present in here and now). In its turn, modo comes from med-, an IndoEuropean root meaning to measure, to give advice, and to heal. These three meanings can vaguely reveal the normative implications inherent to the word modernity as a westernized notion from the very outset. For example, St Augustine used the word "modern" as early as $5^{\text {th }}$ century to contrast "the new Christian era with pagan antiquity", as "a means of describing and legitimizing new institutions, new legal rules, or new scholarly assumptions" (Martinelli, 2005, p. 5). Yet, our contemporary discourses about Modernity are also hardly far from these early functions of the modern in theologicalpolitical discourse. If the monster is initially defined medically as natural disease that overthrows nature, then it seems that modernization could be interpreted as a process of measuring its naturalness; of identifying monstrosity in order to give advice against it and to heal this aberration of nature.

Approaching the same problematic by a reference to Eugenia - an ancient Greek term which means one is well-born - Antonio Negri defines the eugenic as the metaphysical foundation of modern sovereignty as follows: "only those who are good and beautiful, eugenically pure, are entitled to command" (Negri, 2008, p. 194). Against this, he summons the monster, echoing some of the etymological meanings of the term previously discussed:

The monster wanders in the dream and in the imaginary of folly: he is a nightmare for those who are 'beautiful and good': it can exist only as catastrophic destiny that must be atoned, or as divine event (Negri, 2008, p. 194).

Not unlike Negri's critique of the eugenic, Michel Foucault also follows the modern procedures of overlaying, appropriating and colonizing the monstrous since $18^{\text {th }}$ century. He defines monster as a "juridicobiological" notion, for "what defines the monster is the fact that its existence and form is not only a violation of the laws of society but also a violation of the laws of nature" (Foucault, 2003, p. 56). Here, the monster always reveals itself as the limit and the exception: the abnormal.

Against the negative dramatization of monster in Foucault, Deleuze and Guattari use the term "anomalous" instead of "abnormal". For them, whereas abnormal "refers to that which is outside rules" and is individualistic, anomalous "designates ... the cutting edge of 
deterritorialization" and entails a multiplicity (2005, p. 243-44). Monster here becomes affirmative and stands as the creative-resistant or revolutionary force of a situation that functions through "monstrous alliances", in a way that the "originary undertaking" of becomingmonstrous is "a rupture with the central institutions that have established themselves or seek to become established" (Deleuze; Guattari, 2005, p. 247).

Therefore, just as there is a distinction between the revolutionary schizoid process and "the way schizophrenics are produced as clinical cases" (Deleuze; Guattari, 1995, p. 23), one must also distinguish between the affirmative non-identifiable monsters that are always in the process of becoming and alteration, from the identified monsters either trapped in medical, judicial, and penal institutional influence of the constituted power, or turned into the servants of the of the sovereign.

Moreover, the fascination with non-identifiable monsters comes from its affinity to the constituent power: those interrelated forces of becoming that constitute the being, extend its limits, and destroy the barriers of constituted power. And precisely because it is the monster who resides at the limit; on the zone of becomings, alterations, and deterritorializations, on the exclusive zone of constituent power. "The monster is not only event, but positive event", writes Negri, defining the monstrous as "a mechanism of ... (material and/or utopian) construction” (2008, p. 200).

It must be noted here that although the etymological meanings of teras, monstrum, or ifrit can be still heard in the contemporary discourses around the monster, its figure, its body, and its relation to humanity have, of course, changed throughout the history. Despite such differences, the monster everywhere appears as that which challenges the arche, the origin, thus preserving the relevance of its ancient meanings in the present.

\section{Hayulā: the Monstrous Flesh}

In their translation of Aristotelian concepts, early Muslim

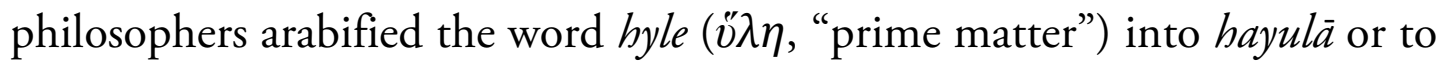
be more exact, al-hayulā al-o’la (الهيولى الاولى, هيو لاى اولى), "the first or the prime hayulä). According to Aristotle, hyle is primordial matter, which serves as the raw and unformed material of, and consequently the 
underlying cause of, all objects. From this perspective, hyle is pure potentiality, which can act itself or be acted upon in order to acquire a form, to be actualized. Hyle as pure potentiality is strictly distinct from form as pure actuality, but their composite construct the identifiable and knowable substance.

In the Arabic and Farsi translations of Aristotle's thought, particularly in the contributions by Ibn-Sina (بن سينا, Avicenna in Latin), hyle in the form of hayula became more clearly determined as a concept. In Islamic philosophy, hayulā as matter is categorized into the Prime (or first) hayula $\bar{a}$, the formless matter which is the pure potentiality to acquire a form, and secondary hayulā, which refers to an already formed matter with the possibility to change its form. In particular, Ibn-Sinnā considers prime hayula as a substance alongside with the Body, the Form, the Soul, and the Intellect (Rezai; Hedayat-Afza, 2013, p. 115; Richardson, 2008, p. 68, p. 87). The natural body is thus a composite of prime hayula with the form, from which the latter is the extensive element of a body, constitutive of its continuity. This argument serves to demonstrate the existence of hayulā, whose form is continuous but in-itself is simply the potentiality to be formed (or deformed). The alleged continuity and extension of body, and its contradictory relation with discreteness, remains unproved in Ibn-Sinnā's philosophy (Rezai; Hedayat-Afza, 2013, p. 115; Richardson, 2008, p. 68, p. 87).

Trying to reject the existence of prime hayulā, however, Shahab al-Din Suhrawardi, another Muslim philosopher, points to the fallacy in Ibn-Sinnās argument by saying that

[...] continuity is not receptive of discreteness; it is true only if the intended continuity is a continuity between two bodies... it is mis-thought that the intended continuity in a single body amounts to the continuity which perishes through discreteness (Suhrawardi 75 apud Rezai; Hedayat-Afza. Translated from the Arabic by the paper's author).

According to Suhrawardi, the connection between prime hayula and its form as an external continuity does not prove itself to be necessary. When the link between potentiality (hayula $)$ and actuality (form) is broken, hayula becomes the pure potentiality, the "potentiality to not-be" as Giorgio Agamben puts it (1999, p. 183) ${ }^{3}$. 
Therefore, the prime hayula embodies the potentiality to not-be, since it is a primordial matter that challenges the position of God as pure Actuality, and does not have or necessitate any natural form or essence. Hayula is thus against any essentialism, refuses issuing itself from the preexisting natural forms, and for this very reason, does not let itself be rigidified or identified. Moreover, when prime hayulä "preserves itself as such in actuality," it exhibits a self-demonstration, just like the monster that demonstrates itself by its mere apparition (hence it is not surprising that hayula have become throughout its history in Farsi language a synonym for monster). Today, however, this word reminds people more of ISIL or of the ifrit than of Aristotle and Ibn-Sīnā.

Commenting on the notion of hyle, Howard Robinson (2014) writes that "'Matter' [hayulā] is rather the name for whatever [...]. Relative to the human body, matter is flesh and blood." To translate this hint into our conceptualization of monster, blood must be removed from the formula, for it has served historically as an essentialist ground - with the exception of its function in the case of vampiric monsters, where it is taken regardless of gender or race. Hence the flesh is the prime matter, the materiality of hayula-monster. This is how Merleau-Ponty conceptualized the flesh as an Element, "in the sense it was used to speak of water, earth, air and fire, that is, in the sense of a general thing, midway between the spatio-temporal individual and the idea, a sort of incarnate principle that brings a style of being wherever there is a fragment of being" (1968, p. 139). The flesh thus becomes the incarnation of the in-between monster, "midway between the spatio-temporal individual [the actual]" and "the idea [the virtual]". For monsters always resides at the limit, at the threshold, at "the cutting edge of deterritorializations" of Being; for the incarnation of the virtual monstrous, the body of the monster, could only be flesh, i.e. the prime matter, alhayulà al-o'la. Hence, the tautology of the monstrous (Foucault, 2003, p. 57): "monster is monster; monster demonstrates".

In the poetics of flesh, where flesh is seen as elemental and common, there will be no anthropomorphic hierarchy, for flesh is the selfdifferentiating continuum of being; heterogeneous, flowing, and plastic. As an Element of being, it is constituent: Flesh incarnates the potentia. Therefore, the only monster proper for this formulation is the creative monster, the joyful schizoid in the process of becoming-schizophrenic; or as 
so many of Mosley's hopeful monsters, "born perhaps slightly before their time; when it's not known if the environment is quite ready for them" (1990, p. 71).

The monstrous body is therefore nothing but flesh: the non-formed, non-natural body proper to that which exceeds sovereign measure and State capture. Moreover, if we displace this ontogenetical perspective to the level of the political, it can be argued that monstrous are the collective bodies who do not let themselves be subjugated to any established identity, and evade becoming organized along pre-existing, and so-called "natural," forms. What kind of body is this monstrous body, and what it can do? - this is the question that shall be answered by the monsters of our age.

\section{Notes}

1 This term was invented by John Williamson, an international economist, in the same year with the Fall of Berlin Wall in 1990, referring to "10 policy instruments about whose proper deployment Washington can muster a reasonable degree of consensus".

2 Caliban appears in Shakespeare's The Tempest. The protagonist of the play is Prospero, the rightful Duke of Milan, who is betrayed by Antonio, his brother, and stranded on an island. The rightful Duke makes the island his base for later revenge and Caliban, who is described as "a savage and deformed Slave", is the native of that island, dethroned by Prospero, the rational colonialist, who in his turn, describes Caliban as a monster: he is as disproportioned in his manners as in his shape. The play has received enormous anti-colonial and decolonial attention, being rewritten and re-interpreted through such lenses. A famous example is Aimé Césaire’s "Une Tempête” (1985).

3 Agamben refers seemingly to Suhrawardi, "a Persian Neoplatonist", to make the distinction between these two kinds of potentialities clearer (Agamben, 1999, p. 270-271).

\section{References}

ADORNO, Theodor W. Minima Moralia: reflections on a damaged life. Trans. E. F. N. Jephcott. London; New York: Verso, 2005.

AGAMBEN, Giorgio. Potentialities: Collected Essays in Philosophy. Trans. Daniel Heller-Roazen. Palo Alto, CA: Stanford University Press, 1999. 
AGAMBEN, Giorgio. The Kingdom And The Glory. Trans. Lorenzo Chiesa and Matteo Mandarini. Palo Alto, CA: Stanford University Press, 2011.

ALI, Ayaan Hirsi. The Quran Is Our Law; Jihad Is Our Way. Wall Street Journal, New York, 2011. Available at: <http:/online.wsj.com/news/articles/ SB10001424052748704132204576136590964621006>. Accessed on: 01 July 2018.

BADIOU, Alain. The Communist Hypothesis. New Left Review, London, v. 49, p. 29-42, 2008.

BARR, James. A Line in the Sand: the Anglo-French struggle for the Middle East, 1914-1948. New York: W.W. Norton \& Co., 2012.

BENJAMIN, Walter. On the Concept of History. In: BENJAMIN, Walter. Selected Writing: 1938-40. Cambridge, MA: Harvard University Press, 2003. P. 389-401.

BOWEN, Innes (Ed.). Syria and the New Lines in the Sand: transcript of a recorder documentary. Prod. Fiona Leach. London, 2013. Available at: <http://downloads.bbc.co.uk/radio4/transcripts/01072013-anlaysis-syria.pdf>. Accessed on: 01 July 2018.

DAYAN, Vedat. Kurdish or Turkish Question? Berlin: Freie Universität Berlin, 2014. Draft-Unpublished.

DELEUZE, Gilles. Foucault. Trans. Seán Hand. Minneapolis: University of Minnesota, 1988.

DELEUZE, Gilles; GUATTARI, Felix. On Anti-Oedipus. Negotiations. New York: Colombia University Press, 1995. P. 13-24.

DeleuZE, Gilles; GUATTARI, Felix. A Thousand Plateaus. Trans. Brian Massumi. Minneapolis: University of Minnesota Press, 2005.

DERRIDA, Jacques. Of Grammatology. Trans. Gayatri Chakravorty Spivak. Baltimore, MD: Johns Hopkins University Press, 1997.

ELIAS, Norbert. The Loneliness of the Dying. New York: Continuum, 2001.

FOUCAULT, Michel. The History of Sexuality. Trans. Robert Hurley. v. I. New York: Pantheon Books, 1978.

FOUCAULT, Michel. Abnormal: lectures at the College de France 1974-1975. Ed. Arnold I. Davidson. Trans. Graham Burchell. London; New York: Verso, 2003. 
GRIGG, Russel; SHARPE, Matthew. In the Name of the Father. In: OPPY, Graham Robert et al. (Ed.). The Antipodean Philosopher. Lanham, Maryland: Lexington Books, 2011. P. 81-89.

HARAWAY, Donna. Simians, Cyborgs and Women: the reinvention of nature. New York: Routledge, 1991.

HARDT, Michael; NEGRI, Antonio. Multitude. New York: Penguin Press, 2004.

HARDT, Michael; NEGRI, Antonio. Commonwealth. Cambridge, MA: The Belknap Press of Harvard University Press, 2009.

KENDALL, Stuart. Georges Bataille. London: Reaktion Books, 2007.

KLOSSOWSKI, Pierre. Nietzsche and the Vicious Circle. Trans. Daniel W. Smith. Chicago: University of Chicago Press, 1997.

LIEDMAN, Sven-Eric. Is content embodied form?. In: KROIS, John Michaels et al. (Ed.). Embodiment in Cognition and Culture. Amsterdam: John Benjamins B. V., 2007. P. 127-131.

LINEBAUGH, Peter; REDIKER, Marcus. The Many-Headed Hydra: sailors, slaves, commoners, and the hidden history of the revolutionary Atlantic. Boston: Beacon Press, 2000.

LOWERY, Wesley. Biden to Islamic State: We will follow you 'to the gates of hell. The Washington Post, Washington D.C., 3 September 2014. Available at: <http://www.washingtonpost.com/blogs/post-politics/wp/2014/09/03/bidento-islamic-state-we-will-follow-you-to-the-gates-of-hell/>. Accessed on: 01 July 2018.

MARTINELLI, Alberto. Global Modernization: rethinking the project of modernity. London; Thousand Oaks: Sage Publications, 2005.

MERLEAU-PONTY, Maurice. The Visible and the Invisible. Trans. Alphonso Lingis. Evanston: Northwestern University Press, 1968.

MOLLENDORF, Peter von. Man as Monster: Eros and Hubris in Plato's Symposium. In: FÖGEN, Thorsten; LEE, Mireille M. Bodies and Boundaries in Graeco-Roman Antiquity. Berlin: Walter de Gruyter GmbH, 2009. P. 87111.

MOSLEY, Nicholas. Hopeful Monsters. Elmwood Park: Dalkey Archive Press, 1990. 
NEGRI, Antonio. The Political Monster: Power and Naked Life. In: CASARINO, Cesare; NEGRI, Antonio. In Praise of the Common: A Conversation on Philosophy and Politics. Trans. Maurizia Boscagli. Minneapolis: University of Minnesota Press, 2008. P. 193-218.

O’SUlLIVAN, Christopher D. Sykes-Picot Treaty. In: PAGE, Melvin E. Colonialism: An International Social, Cultural, and Political Encyclopedia. Santa Barbara; Denver; Oxford: ABC_CLIO, 2003. P. 567.

REZAI, Mohammad Javad; HEDAYAT-AFZA, Mahmoud. ( رضايی، محمد جوادو و ديدكاه سهروردى 'Suhrawardi's Viewpoint on Peripatetic Hayulā (دحمود هدايتافزا 'دربارهى هيو لاى مشائى ('). Sino Wisdom, v. 49, p. 117-137, 2013.

RICHARDSON, Kara. The Metaphysics of Agency: Avicenna and his Legacy. PhD Thesis - Department of Philosophy, University of Toronto, Toronto, 2008.

ROBINSON, Howard. Substance. In: ZALTA, Edward N. (Ed.). The Stanford

Encyclopedia of Philosophy. Spring 2014. n.d. Available at: <http://plato.stanford.edu/archives/spr2014/entries/substance>. Accessed on: 01 July 2018.

ROJAVA CANTONS. The Constitution of the Rojava Cantons. February 2014. Available at: <http://civiroglu.net/the-constitution-of-the-rojava-cantons/>. Accessed on: 02 July 2018.

SHAKESPEARE, William. The Tempest. Ed. David Hamilton Horne. New Haven: Yale University Press, 1955.

TALEB, Julia. From Assad to ISIS, a Tale of Syrian Resistance. Waging Nonviolence, 22 August $2014 . \quad$ Available at: $<$ http://wagingnonviolence.org/feature/ assad-isis-tale-resistance/>. Accessed on: 01 July 2018.

TANENBAUM, Jan Karl. Sykes-Picot Agreement. In: TUCKER, Spencer C.; WOOD, Laura Matysek; MURP, Justin D. The European Powers in the First World War: An Encyclopedia. London: Taylor \& Francis, 1999. P. 67778.

TAŞTEKIN, Fehim. Erdogan plays 'Arab card' in Kobani. Al-Monitor, 28 October 2014. Available at: <http://www.al-monitor.com/pulse/originals/2014/ 10/turkey-kobani-erdogan-deals-arab-card.html>. Accessed on: 01 July 2018. 
Iman Ganji is Doctoral Candidate, International Research Training Group Interart, Freie Universität Berlin, Germany. Visiting Research Fellow, Center for Cultural Studies, Goldsmiths University, UK. Double MA in International Performance Art Research, Netherlands; United Kingdom; Serbia. MA in Philosophy of Arts, Art University of Tehran, Iran.

ORCID: http://orcid.org/0000-0002-4164-9434

E-mail: iman.gnj@gmail.com

This original paper, proofread by Ananyr Porto Fajardo, is also published in Portuguese in this issue of the journal.

Received on 30 July, 2018 Accepted on 18 December, 2018

This is an open-access article distributed under the terms of the Creative Commons Attribution License 4.0 International. Available at: <http://creative commons.org/licenses/by/4.0>. 